Volume 10. Nomor 2. December 2015
Pandecta
http://journal.unnes.ac.id/nju/index.php/pandecta

\title{
Model Penegakan Hukum Anak yang Berhadapan dengan Hukum dalam Proses Penyidikan
}

\author{
Hamidah Abdurrachman ${ }^{1}{ }^{\bowtie}$, Fajar Ari Sudewo ${ }^{1}$, Dyah Irma Permanasari ${ }^{1}$ \\ ${ }^{1}$ Fakultas Hukum Universitas Pancasakti Tegal, Indonesia \\ Permalink/DOI http://dx.doi.org/10.15294/pandecta.v10i2.
}

\begin{abstract}
Article History
Abstrak

Received : August 2015;

Upaya memberikan perlindungan terhadap Anak yang berhadapan dengan hukum dalam Accepted: September 2015; Sistem Peradilan Pidana Anak menunjukkan perkembangan yang sangat berarti. Selama Published: September 2015

\section{Keywords:}

the child in conflict the law, restorative justice, police ini terhadap anak yang berkonflik dengan hukum, ditangani secara umum seperti orang dewasa. Anak-anak tersebut melewati proses hukum tanpa ada pendampingan bahkan segera dilakukan upaya paksa berupa penangkapan dan penahanan sehingga anak mengalami putus sekolah. Undang-Undang No. 11 Tahun 2012 tentang Sistem Peradilan Pidana Anak meletakkan fondasi perlindungan anak dengan pendekatan Keadilan Restoratif yaitu dalam penyelesaian perkara melibatkan pelaku, korban, keluarga pelaku/ korban dan pihak lain yang terkait untuk bersama-sama mencari penyelesaian yang adil dengan menekankan pemulihan kembali pada keadaan semula dan bukan pembalasan. Keadilan restoratif ini diwujudkan melalui Diversi yaitu pengalihan penyelesaian perkara anak dari proses peradilan pidana ke proses ke luar pengadilan pidana. Hasil penelitian ini menunjukkan bahwa di Jawa Tengah kasus anak yang berkonflik dengan hukum secara umum diselesaikan melalui jalur diversi dan sebagian lainnya diproses menggunakan berdasarkan KUHAP atau jalur pidana. Hal lainnya meskipun sudah menerapkan jalur diversi terhadap anak yang berkonflik dengan hukum namun belum ada keseragaman atau kesamaan model diversi sebagaimana yang diamanatkan di dalam Undang-Undang Nomor 11 Tahun 2012 tentang Sistem Peradilan Pidana Anak.
\end{abstract}

\begin{abstract}
Efforts to provide protection against Children in conflict with the law in the Criminal Justice System Child shows a very significant development. During against children in conflict with the law, generally handled as an adult. These children pass through the legal process without immediate assistance even forceful measures in the form of arrest and detention so that children have dropped out of school. Law No. 11 Year 2012 on the Criminal Justice System Child laid the foundation of child protection approach Restorative Justice that in settling disputes involving offenders, victims, family offender/victim and other relevant parties to work together to find a fair settlement with the emphasis on restoring back to its original state and not retaliation. Restorative justice is realized through the transfer of settling disputes Diversion namely children from the criminal justice process to a process outside the criminal court. The results of this research showed that in Central Java case of children in conflict with the law are generally resolved through the diversion and some processed using by the Criminal Code or the criminal path. Another thing despite applying diversion path towards children in conflict with the law but there is no uniformity or sameness models of diversion as mandated in Law No. 11 Year 2012 on Child Criminal Justice System
\end{abstract}




\section{Pendahuluan}

Anak adalah bagian dari warga negara yang harus dilindungi karena mereka merupakan generasi bangsa yang dimasa yang akan datang akan melanjutkan kepemimpinan bangsa Indonesia. Kelangsungan kehidupan anak adalah tanggungjawab orangtua, yang tidak boleh diabaikan. Pasal 45 UU No. 1 Tahun 1974 tentang Pokok-Pokok Perkawinan, menentukan bahwa orangtua wajib memelihara dan mendidik anak-anak yang belum dewasa sampai anak-anak yang bersangkutan dewasa atau dapat berdiri sendiri. Pasal 9 UU Nomor 4 Tahun 1979 tentang Kesejahteraan Anak, orangtua merupakan yang pertama-tama bertanggungjawab atas terwujudnya kesejahteraan anak baik rohami, jasmani maupun sosial.

Pada hakikatnya anak tidak dapat melindungi diri sendiri dari berbagai macam tindakan yang menimbukan kerugian mental, fisik, sosial dalam berbagai bidang kehidupan dan penghidupan. Anak harus dibantu oleh orang lain dalam melindungi dirinya, mengingat situasi dan kondisinya, khususnya dalam pelaksanaan Peradilan Pidana Anak yang asing bagi dirinya. Anak perlu perlindungan dari kesalahan penerapan peraturan perundang-undangan yang diberlakukan terhadap dirinya, yang menimbulkan kerugian mental, fisik dan sosial. Perlindungan anak dalam hal ini disebut dengan perlindungan hukum/ yuridis.

Peradilan adalah tiang teras dan landasan negara hukum. Peraturan hukum diciptakan memberikan faedah apabila ada peradilan yang berdiri kokoh/kuat dan bebas dari pengaruh apapun yang dapat memberikan isi dan kekuatan kepada kaidah-kaidah hukum yang diletakkan dalam undang-undang dan peraturan hukum lainnya. Kedudukan peradilan dalam negara hukum dan masyarakat demokrasi, masih tetap diandalkan : (1) sebagai "katup penekan" atas segala pelanggaran hukum, ketertiban masyarakat dan pelanggaran ketertiban umum; (2) peradilan masih tetap diharapkan berperan sebagai tempat terakhir mencapai kebenaran dan keadilan sehingga pengadilan masih diandalkan sebagai bahan yang berfungsi menegakkan ke- benaran dan keadilan (Harahap, 1997:237). Proses Peradilan Pidana Anak mulai dari penyidikan, penuntutan, pengadilan dan dalam menjalankan putusan pengadilan di Lembaga Pemasyarakatan Anak wajib dilakukan oleh pejabat-pejabat yang terdidik khusus atau setidaknya mengetahui tentang masalah Anak Nakal.

Sejarah panjang perjalanan perlindungan anak yang berkeadilan. Dalam masyarakat internasional, gagasan mengenai hak anak bermula dari berakhirnya Perang Dunia I, sebagai reaksi atas penderitaan yang timbul akibat bencana peperangan terutama yang alami oleh kaum perempuan dan anak-anak. Kemudian tahun 1924, untuk pertama kalinya Deklarasi Hak Anak yang dikembangkan oleh Eglantyne Jebb tentang sepuluh butir pernyataan tentang Hak Anak diadopsi secara internasional oleh Liga Bangsa-Bangsa. Deklarasi ini kenal juga dengan deklarasi Janewa. Tahun 2 September 1990, berlaku Konvensi Hak Anak. Sesuai dengan ketentuan Konvensi Hak Anak (Convention On The Rights Of The Child) yang diratifikasi oleh pemerintah Indonesia melalui Keputusan Presiden Nomor 36 Tahun 1990 kemudian dituangkan dalam Undang-Undang No. 4 Tahun 1979 tentang Kesejahteraan Anak dan Undang-Undang Nomor 23 Tahun 2002 tentang Perlindungan Anak dan Undang-Undang Nomor 11 tahun 2012 tentang Sistem Peradilan Pidana Anak yang kesemuanya mengemukakan prinsipprinsip umum perlindungan anak, yaitu non diskriminasi, kepentingan terbaik bagi anak, kelangsungan hidup dan tumbuh kembang dan menghargai partisipasi anak.

Sembilan klaster pengaduan Komisi Perlindungan Anak Indonesai kasus anak berhadapan dengan hukum menempati posisi tertinggi. Hingga april 2015 ada 6.006 kasus anak berhadapan dengan hukum, dan kemudian berdasarkan data pada Kementerian Hukum dan Hak Asasi Manusia, pada tahun 2013 yang lalu terdapat 6.505 kasus anak yang berkonflik dengan hukum yang kemudian atas perkara anak tersebut tersebut, sebanyak 4.622 anak terpaksa dipidana dan dimasukkan ke dalam penjara termasuk di dalamnya terdapat 3.323 anak yang berusia di bawah 16 tahun (http:www//acade- 
mia.com_anak_yang-berhadapan_denganhukum.html diakses 29 April 2014).

Anak merupakan amanah dari Tuhan Yang Maha Esa yang dalam melekat harkat dan martabat sebagai manusia seutuhnya. Hak-Hak setiap anak mempunyai hal yang wajib dijunjung tinggi tanpa anak tersebut diminta. Perlindungan Anak berkaitan erat dengan keadilan, karena dalam Peradilan Pidana Anak, rasa keadilan para penegak hukum yang menangani Anak mempengaruhi tindakan-tindakannya. Apabila keadilan dihubungkan dengan perlindungan anak maka dalam keadilan tercermin perlindungan anak yang baik atau perlindungan anak yang baik mencerminkan keadilan yang implementasikan adalah hak-hak anak.

Perlindungan hukum bagi anak dapat dilakukan sebagai upaya perlindungan hukum terhadap kebebasan dan hak asasi anak. Perlindungan terhadap anak ini mencakup kepentingan yang berhubungan dengan kesejahteraan anak. Perlindungan anak-anak yang berhadapan dengan hukum merupakan tanggung jawab besama aparat penegak hukum. Tidak hanya anak sebagai pelaku, namun mencakup anak sebagai korban dan saksi. Aparat penegak hukum yang terlibat dalam penanganan $\mathrm{ABH}$ agar tidak hanya mengacu pada pada UU Nomor 11 Tahun 2012 tentang Sistem Peradilan Pidana Anak atau peraturan perundang-undangan lainnya yang berkaitan dengan $\mathrm{ABH}$, namun lebih mengutamakan perdamaian daripada proses hukum formal yang diberlakukan 2 tahun setelah UU SPPA diundangkan atau 1 Agustus 2014 (Pasal 10 No. 11 Tahun 2012).

Kepolisian, aparat penegak hukum yang mempunyai peranan yang besar dalam penanganan $\mathrm{ABH}$ karena pintu pertama penanganan anak yang berhadapan dengan hukum. Namun pada pelaksanaan, lebih banyak menekankan pada prosedur hukum positif saja tanpa mempertimbangkan kepentingan anak, akibatnya anak yang berhadapan dengan hukum, mendapatkan kekerasan dan penganiayaan saat menangkap dan memeriksa dalam proses penyusunan BAP, juga ketika anak-anak ini berada dalam tahanan polisi, meskipun tidak seintensif saat pemeriksaan yang oleh anak-anak sering disebut dengan diverbal dan digulung untuk mengidentifikasi kekerasan fisik yang mereka terima. Perlakuan polisi yang menangkap dan menginterogasi (memeriksa perkara anak) untuk pembuatan BAP sangat lekat dalam benak anak-anak. Kenangan ini lebih diingat sebagai pengalaman buruk yang menyakitkan tanpa ada sisi positifnya bagi kepentingan anak (Swanson dkk, 1984:4).

Berdasarkan kenyataan itulah maka perlu adanya model penanganan yang pasti dalam menangani Anak Berhadapan dengan Hukum yang mengedepankan pemulihan bagi anak sebagai pelaku, korban maupun saksi daripada penghukuman.

Penelitian mengenai Model Penegakan Hukum terhadap Anak Yang Berhadapan dengan Hukum dalam Proses Penyidikan berdasarkan Undang-Undang Nomor 11 Tahun 2012 Tentang Sistem Peradilan Pidana Anak untuk diaplikasikan dan dilaksanakan oleh pihak Kepolisian. Pemberlakuan Undang-undang Nomor 11 Tahun 2012 tentang Sistem Peradilan Pidana Anak mengetengahkan sebuah permasalahan yaitu bagaimana model yang memadai dalam penanganan hukum terhadap Anak yang Berhadapan dengan Hukum dalam proses Penyidikan Berdasarkan Undang-Undang Nomor 11 Tahun 2012 tentang Sistem Peradilan Pidana Anak.

\section{Metode Penelitian}

Penelitian ini adalah penelitian hukum empiris, yaitu menelaah pelaksanaan suatu ketentuan hukum di masyarakat, kemudian menganalisis untuk menentukan kebijakan hukum pada masa yang akan datang (Widodo, 2013:35). Penggolongan jenis penelitian ini didasarkan pada maksud penelitian ini yakni mendeskripsikan model penegakan hukum bagi anak sebagai pelaku tindak pidana dalam proses penyidikan kaitannya dengan pemberlakuan Undang-undang Nomor 11 Tahun 2012 tentang Sistem Peradilan Pidana Anak.

Penelitian ini dilakukan di Polres-Polres di wilayah hukum Wilayah Hukum Polda Jawa Tengah dengan pertimbangan peneliti sudah pernah terjun langsung ke lapangan terutama dalam kegiatan akademik peneliti 
serta pertimbangan bahwa Undang-undang Nomor 11 Tahun 2012 tentang Sistem Peradilan Pidana Anak merupakan produk perundang-undangan yang baru yang akan mengubah paradigma penanganan anak yang berhadapan dengan hukum terutama di tingkat penyidikan

\section{Hasil Penelitian dan Pembahasan}

Penelitian ini terbagi menjadi 6 (enam) Kepolisian Sektor yang ada di wilayah Polda Jawa Tengah yang meliputi Polres Pati yang mewakili eks Karesidenan Pati, Polres Purworejo yang mewakili eks Karesidenan Kedu, Polrestabes Semarang yang mewakili eks Karesidenan Semarang, Polres Banyumas yang mewakili eks Karesidenan Banyumas, Polresta Surakarta mewakili Karesidenan Surakarta dan Polresta Tegal yang mewakili Eks Karesidenan Pekalongan dapat dilihat pada Tabel 1.

Dalam pelaksanaan penelitian di lapangan ditemukan beberapa fakta terkait pelaksanaan penyidikan berdasarkan Undang-Undang Nomor 11 Tahun 2014 tentang Sistem Peradilan Pidana Anak sebagai berikut :

a. Belum semua anggota Polri yang bertugas di Unit PPA belum mengikuti Pelatihan UU SPPA;

b. Belum ada sosialisai di masyarakat sehingga ada kesan Polri melepaskan pelaku;

c. Ada kesan Polisi tidak mau repot dengan proses diversi karena waktu yang diberikan UU dalam menangani perkara anak sangat terbatas;

d. Di beberapa sample belum ada tim pendamping dengan bapas, relawan, LSM, NGO Anak belum siap untuk membantu Polisi;

e. Di beberapa daerah sample belum ada perhatian dan prioritas dari pimpinan terhadap pelaksanaan UU SPPA;

f. Dibeberapa daerah sample, belum tersedia sarana ruangan sebagai tempat khusus mediasi;

g. Masih ada perbedaan pendapat antara jaksa dan polisi terkait dengan pelaku anak yang berusia kurang dari 14 (empat belas) tahun namun telah melakukan tindak pidana berulang kali;

h. Belum ada SOP/Juklak/Juknis sebagai pelaksanaan UU SPPA;

i. Model Penanganan masih beragam karena terbatasnya personil penyidik

j. Dibeberapa daerah sample, untuk meminta Bapas melakukan pendampingan masih sangat formal dan lokasinya jauh, padahal waktu penanganan $\mathrm{ABH}$ terbatas.

\section{Polres Pati}

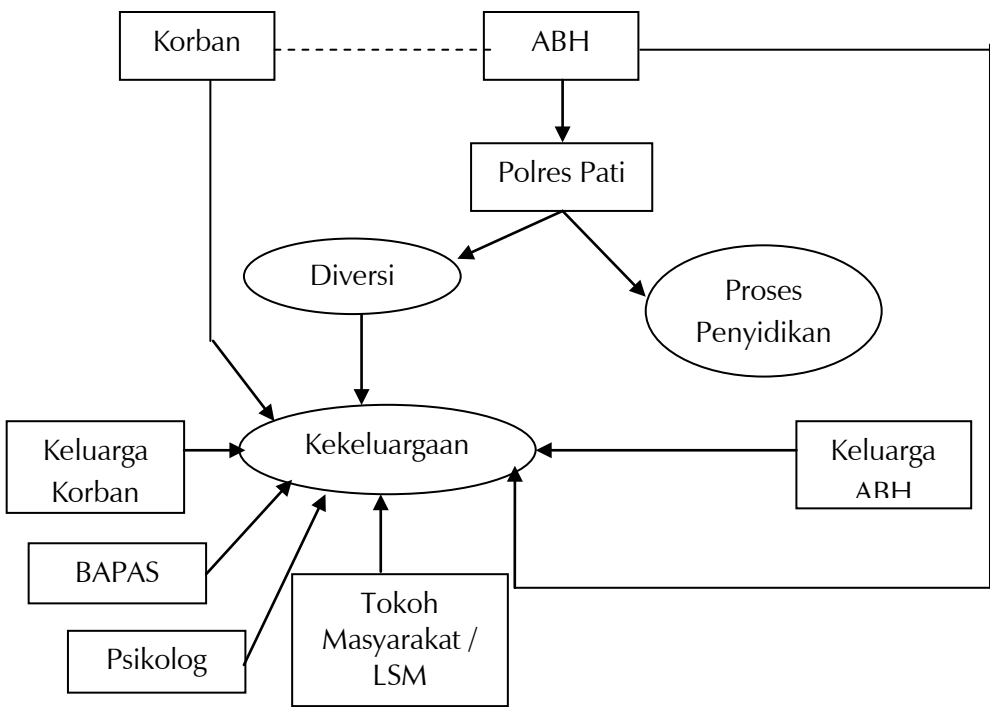

Gambar 1. Model Penyelesaian Anak Yang Berhadapan dengan Hukum melalui Diversi di Polres Pati 
Tabel 1 Data Penanganan ABH di Wilayah Polda Jawa Tengah Tahun 2014-2015

\begin{tabular}{|c|c|c|c|c|c|}
\hline \multirow{2}{*}{ No } & \multirow{2}{*}{ Sample } & \multirow{2}{*}{$\begin{array}{l}\text { Jumlah } \\
\text { Kasus }\end{array}$} & \multicolumn{2}{|c|}{ Penanganan } & \multirow{2}{*}{ Catatan } \\
\hline & & & Diversi & Peradilan & \\
\hline 1. & Polres Pati & 8 & 3 & 5 & $\begin{array}{l}\text { - Peradilan di tempuh karena pelaku } \\
\text { adalah residivis. } \\
\text { - } \\
\text { Diversi gagal karena pihak Korban } \\
\text { tidak menghendaki. } \\
\text { - Tidak tersedia LSM/NGO Anak } \\
\text { yang melakukan pendampingan } \\
\text { terhadap anak korban/pelaku/ saksi }\end{array}$ \\
\hline 2. & $\begin{array}{l}\text { Polres } \\
\text { Purworejo }\end{array}$ & 45 & 7 & 38 & $\begin{array}{l}\text { - Peradilan di tempuh karena pelaku } \\
\text { adalah residivis. } \\
\text { Diversi gagal karena pihak Korban } \\
\text { tidak menghendaki. } \\
\text { - } \quad \text { Tidak tersedia LSM/NGO Anak } \\
\text { yang melakukan pendampingan } \\
\text { terhadap anak korban/pelaku/ saksi } \\
\text { - Permohonan pendampingan Bapas } \\
\text { terlalu prosedural padahal waktu } \\
\text { sangat terbatas. }\end{array}$ \\
\hline 3. & Polres Tegal & 16 & 10 & 6 & $\begin{array}{l}\text { Peradilan di tempuh karena pelaku } \\
\text { adalah residivis } \\
\text { Diversi gagal karena pihak Korban } \\
\text { tidak menghendaki. } \\
\text { - Tidak tersedia LSM/NGO Anak } \\
\text { yang melakukan pendampingan } \\
\text { terhadap anak korban/pelaku/ } \\
\text { saksi } \\
\text { - Permohonan pendampingan Bapas } \\
\text { terlalu prosedural padahal waktu } \\
\text { sangat terbatas. } \\
\end{array}$ \\
\hline 4. & $\begin{array}{l}\text { Polres } \\
\text { Semarang }\end{array}$ & 55 & 30 & 35 & $\begin{array}{l}\text { - Peradilan di tempuh karena pelaku } \\
\text { adalah residivis. } \\
\text { - } \\
\text { Diversi gagal karena pihak Korban } \\
\text { tidak menghendaki. }\end{array}$ \\
\hline 5. & $\begin{array}{l}\text { Polres } \\
\text { Banyumas }\end{array}$ & 54 & 38 & 16 & 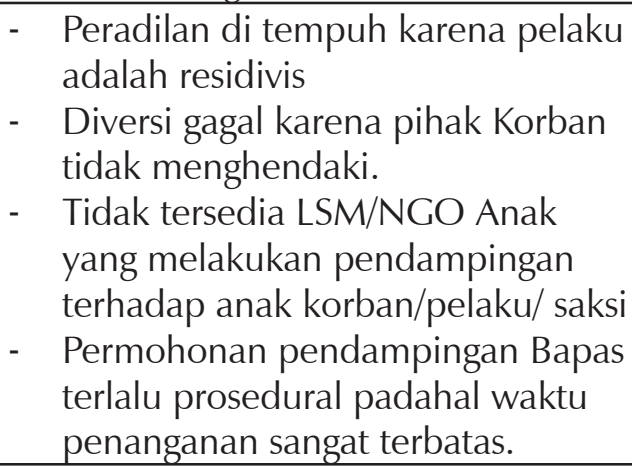 \\
\hline 6. & $\begin{array}{l}\text { Polresta } \\
\text { Surakarta }\end{array}$ & 12 & 12 & 0 & \\
\hline
\end{tabular}


2. Polres Purworejo

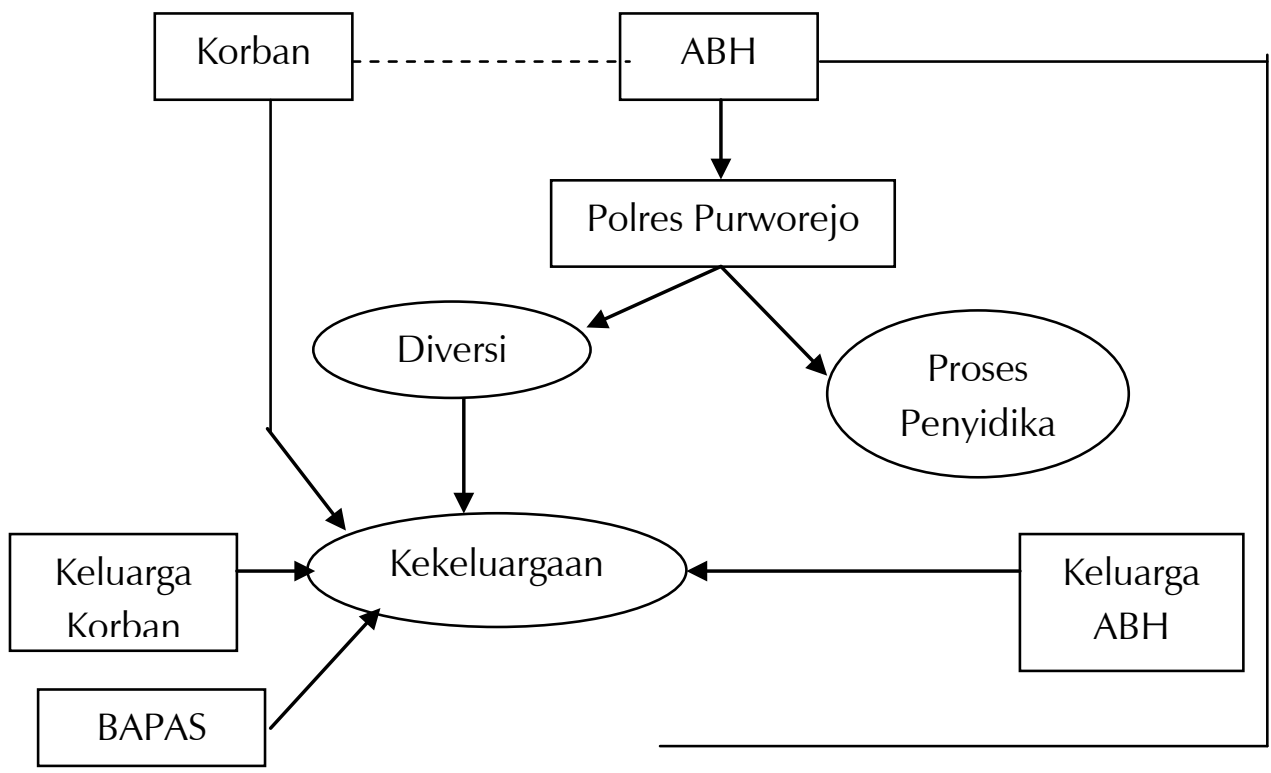

Gambar 2. Model Penyelesaian Anak Yang Berkonflik dengan Hukum melalui Diversi di Polres Purworejo

3. Polres Tegal

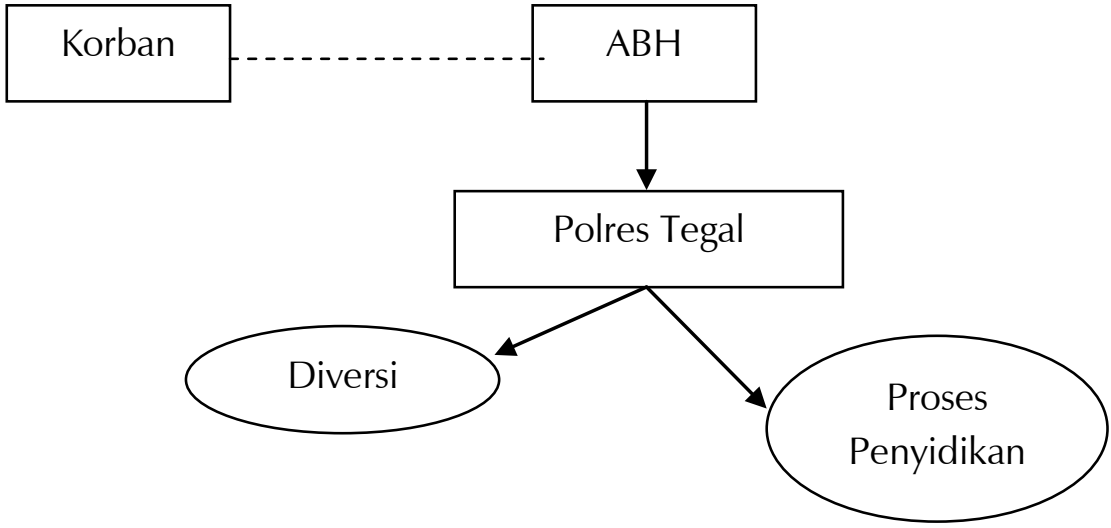

Gambar 3. Model Penyelesaian Anak Yang Berhadapan dengan Hukum melalui Diversi di Polres Tegal 
4. Polrestabes Semarang

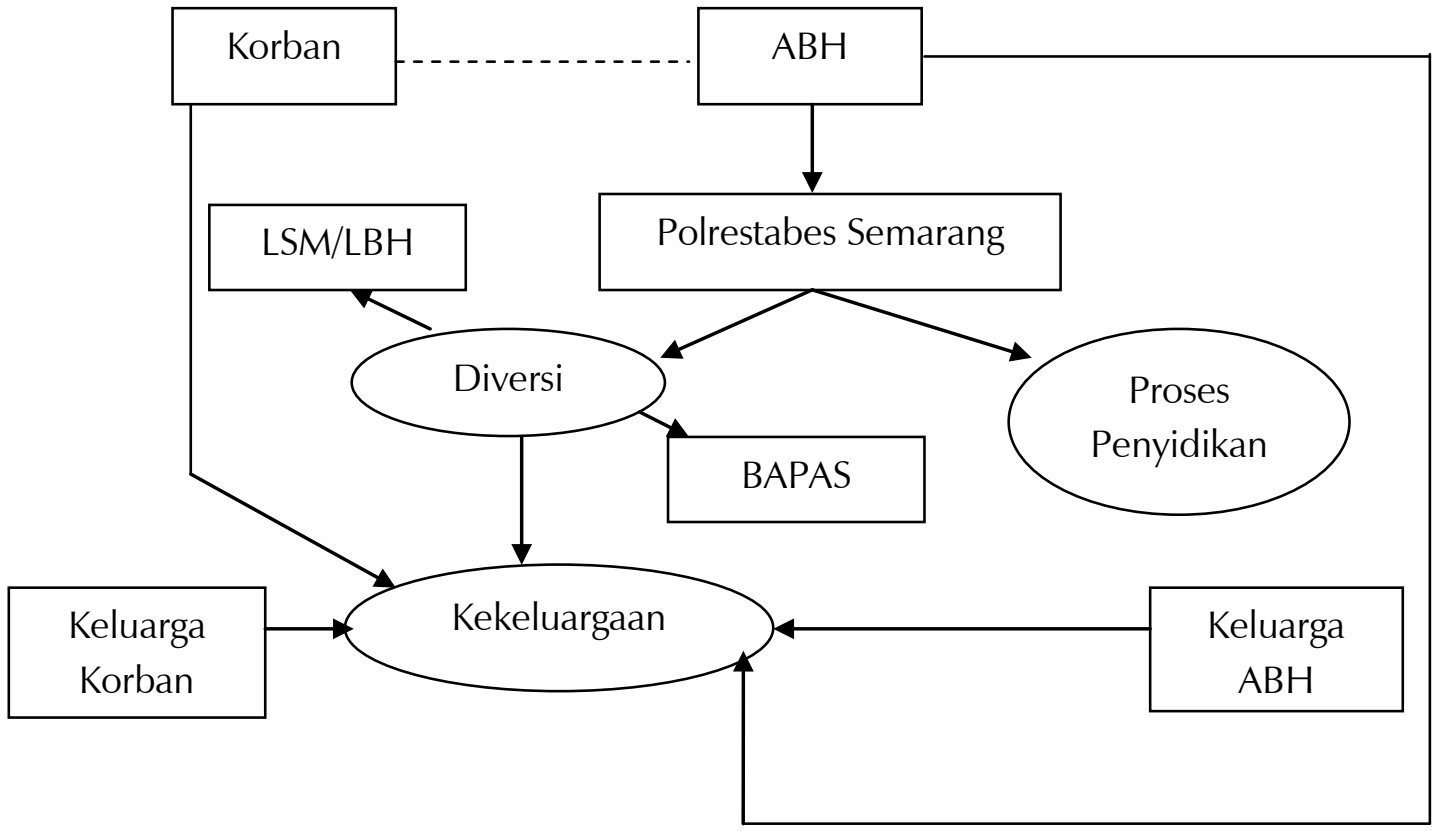

Gambar 4. Model Penyelesaian Anak Yang Berberhadapan dengan Hukum melalui Diversi di Polresta Semarang

5. Polres Banyumas

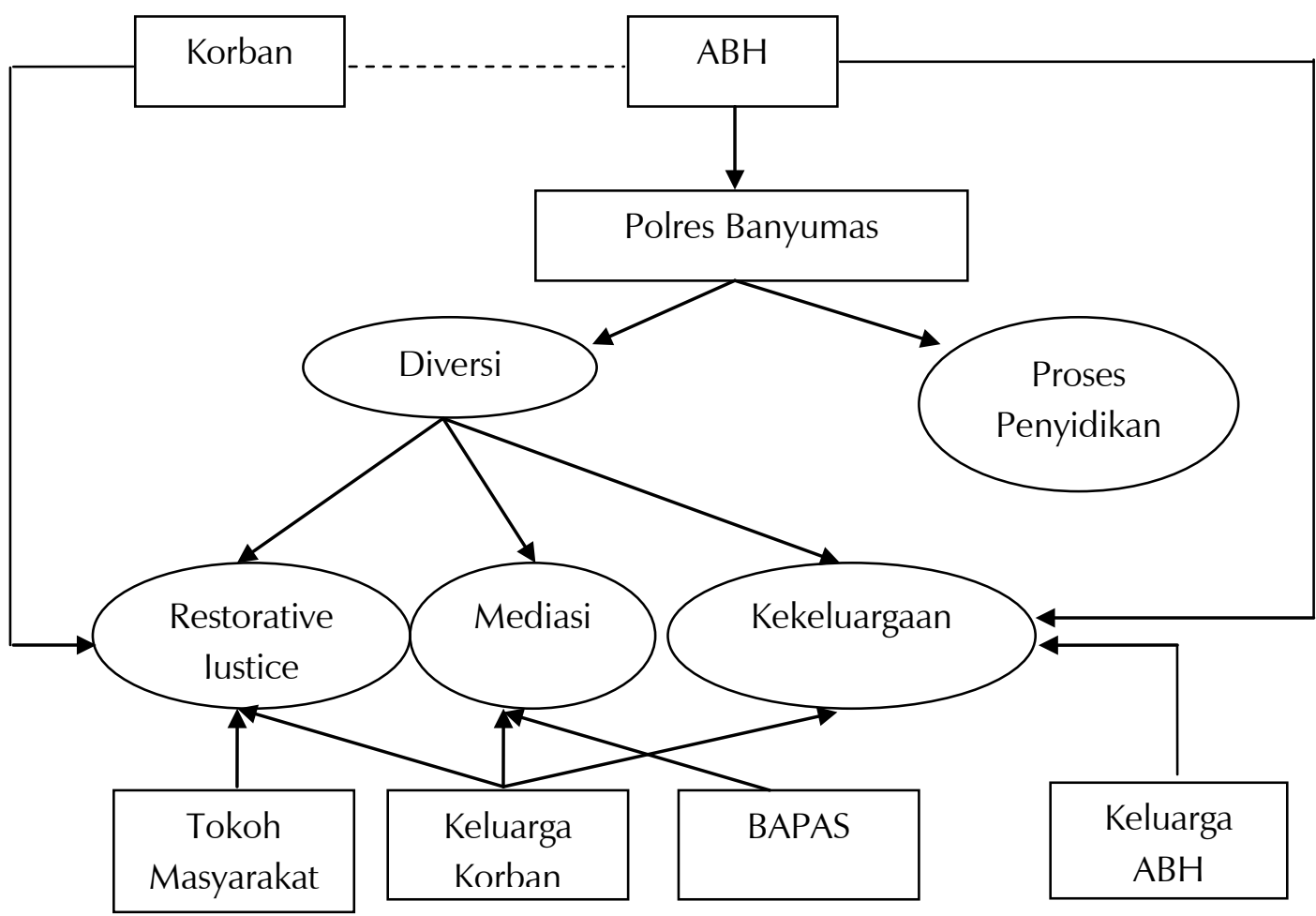

Gambar 5. Model Penyelesaian Anak Yang Berhadapan dengan Hukum melalui Diversi di Polres Banyumas 


\section{Polresta Surakarta}

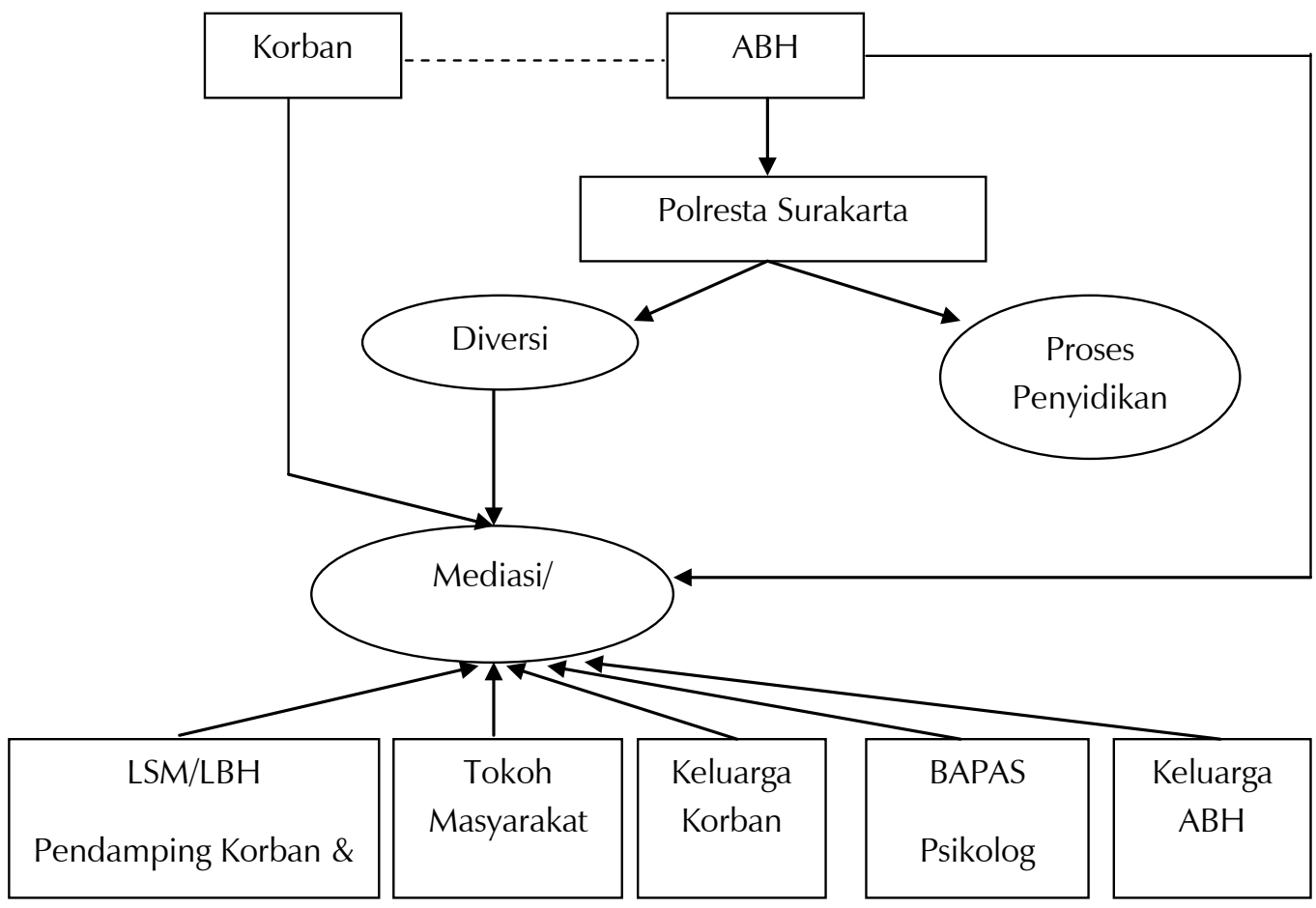

Gambar 6. Model Penyelesaian Anak Yang Berhadapan dengan Hukum melalui Diversi di Polresta Surakarta

Dalam UU No. 11 Tahun 2012, proses penanganan anak yang berhadapan dengan hukum erat kaitannya dengan penegakan hukum itu sendiri. Dimana dalam Sistem Peradilan Pidana Anak telah diatur tentang ketentuan terhadap anak-anak yang melakukan tindak pidana. Dalam undang-undang nomor 11 tahun 2012 memberikan perbedaan perlakuan dan perlindungan terhadap pelaksanaan hak-hak anak, khususnya anak sebagai tersangka dalam proses peradilan pidana yaitu meliputi seluruh prosedur acara pidana, mulai dari penyelidikan, penyidikan dan berakhir pada pelaksanaan pidana. Dalam proses penyidikan anak, tidak hanya sekedar mencari bukti, serta penyebab kejadian, tetapi juga diharapkan dapat mengetahui latar belakang kehidupan anak tersebut sebagai pertimbangan dalam menentukan tuntutan.

Pasal 1 angka 2 UU No. 11 Tahun 2012 dirumuskan Anak yang berhadapan dengan hukum adalah anak yang yang berkonflik dengan hukum, anak yang menjadi korban tindak pidana dan anak yang menjadi saksi tindak pidana; kemudian Pasal 1 angka 3 UU No. 11 Tahun 2012 menjelaskan Anak yang berhadapan dengan hukum adalah anak yang telah mencapai usia 12 (dua belas) tahun tetapi belum mencapai usia 18 (delapan belas) tahun yang diduga melakukan tindak pidana.

Diatur lebih lanjut dalam Pasal 5 (1) Sistem Peradilan Pidana Anak wajib mengutamakan pendekatan Keadilan Restoratif (2) meliputi a. penyidikan dan penuntutan pidana anak dilaksanakan sesuai dengan ketentuan peraturan perundangan; b. persidangan anak yang dilakukan oleh pengadilan dilingkungan peradilan umum; dan c. pembinaan, pembimbingan, pengawasan, dan/atau pendampingan selama proses pelaksanaan pidana atau tindakan dan setelah menjalani pidana atau tindakan.

Pelaksanaan ketentuan Pasal 5 tersebut huruf a dan b maka ada kewajiban bagi Polri untuk melakukan Diversi. Tujuan dilakukan Diversi adalah mencapai perdamaian antara korban dan Anak; menyelesaikan perkara 
Anak diluar proses peradilan; menghindarkan Anak dari perampasan kemerdekaan; mendorong masyarakat untuk berpartisipasi dan menanamkan rasa tanggung jawab kepada Anak. Pembatasan Diversi dilakukan dalam hal tindak pidana yang dilakukan Anak yang diancam dengan pidana penjara dibawah tujuh tahun dan bukan merupakan pengulangan tindak pidana. Meskipun demikian pelaksanaan Diversi wajib memperhatikan kepentingan korban; kesejahtraan dan tanggung jawab anak; penghindaran stigma negatif; keharmonisan masyarakat dan kepatutan, kesusilaan dan ketertiban umum.

Perlindungan hukum terhadap anak dalam proses peradilan dilakukan sejak tingkat penyelidikan, penyidikan, penuntutan, pemeriksaan di sidang pengadilan sampai pada pelaksanaan putusan pengadilan tersebut.

\section{Penyidik}

Pasal 26 ayat (1) UU No. 11 tahun 2012 "Penyidikan terhadap perkara anak dilakukan oleh penyidik yang ditetapkan berdasarkan Surat Keputusan Kepala Kepolisian RI atau pejabat lain yang ditunjuk oleh Kapolri".

Penyidik Polri yang diangkat oleh Kapolri dengan Surat Keputusan Khusus untuk kepentingan tersebut, oleh UU No 11 Tahun 2012 Pasal 26 ayat (3) menetapkan syarat-syarat yang harus dipenuhi oleh seorang penyidik adalah telah berpengalaman sebagai penyidik; mempunyai minat, perhatian, dedikasi dan memahami masalah anak; telah mengikuti pelatihan teknik tentang peradilan anak. Namun apabila belum terdapat penyidik yang memenuhi persyaratan tersebut maka tugas penyidikan dilakukan oleh penyidik yang melakukan tugas penyidikan tindak pidana yang dilakukan oleh orang dewasa.

\section{Proses Penyidikan}

Proses penyidikan terhadap $\mathrm{ABH}$ harus dalam suasana kekeluargaan sebagaimana diatur dalam Pasal 18 yaitu:

"Dalam menangani perkara Anak, Anak Korban, dan/atau Anak Saksi, Pembimbing Kemasyarakatan, Pekerja Sosial Profesional dan Tenaga Kesejahteraan Sosial, Penyidik, Penuntut Umum, Hakim dan Advokat atau pemberi bantuan hukum lainnya wajib memperhatikan kepentingan terbaik bagi Anak dan mengusahakan suasana kekeluargaan tetap terpelihara".

Pasal 19 ayat (1), Proses penyidikan anak, wajib dirahasiakan. Dimana seluruh tindakan penyidik berupa penangkapan, penahanan dan tindakan lain yang dilakukan mulai dari tahap penyelidikan hingga tahap penyidikan wajib dilakukan secara rahasia.

Selanjutnya dalam Pasal 20 dirumuskan dalam hal tindak pidana yang dilakukan anak yang belumberumur 18 tahun diajukan ke sidang pengadilan setelah anak yang bersangkutan melampaui batas umur 18 tahun, tetapi belum mencapai umur 21 tahun, anak tetap tetap diajukan ke sidang anak. Dalam hal anak belum berumur 12 tahun melakukan atau digugat melakukan tindak pidana, penyidik, pembimbing kemasyarakatan dan pekerja professional mengambil keputusan untuk menyerahkan kembali kepada orang tua/wali; mengikutsertakan dalam program pendidikan, pembinaan dan pembimbingan di instansi pemerintah atau LPKS di instansi yang menangani bidang kesejahtraan sosial baik ditingkat pusat maupun daerah paling lama 6 bulan. Ketentuan ini dapat diperpanjang atas hasil evaluasi Bapas dalam hal anak masih memerlukan pendidikan, pembinaan dan pembimbingan lanjutan, paling lama 6 bulan.

Pasal 23 UU No.11 Tahun 2012 tentang Sistem Peradilan Pidana Anak, dalam setiap tingkat pemeriksaan anak wajib diberikan bantuan Hukum dan didampingi Pembimbing Kemasyarakatan.

Dalam proses penyidikan, sesuai dengan Pasal 27 ayat (1) dan (2) UU No 11 Tahun 2012, penyidik wajib meminta pertimbangan atau saran dari pembimbing kemasyarakatan, dan apabila perlu juga dapat meminta pertimbangan dan saran dari ahli pendidikan, ahli kesehatan jiwa, ahli agama atau petugas kemasyarakatan lainnya.

\section{Penahanan}

Penahanan Anak harus memperhatikan kepentingan yang menyangkut pertumbuhan dan perkembangan anak baik fisik, mental maupun sosial anak serta mempertimbangkan kepentingan masyarakat misalnya den- 
gan ditahannya anak akan membuat masyarakat aman dan tentram.

Pasal 33 ayat (1) menentukan bahwa untuk kepentingan penyidikan, penyidik berwenang melakukan penahanan anak yang diduga keras melakukan tindak pidana (kenakalan) berdasarkan bukti permulaan yang cukup".

Pasal 32 ayat (2) huruf a dan b menegaskan bahwa Penahanan dilakukan apabila anak melakukan tindak pidana penjara berusia 14 tahun ke atas dan diancam pidana penjara 7 thaun ke atas yang telah ditentukan oleh undang-undang.

Terkait dengan penahanan, penahanan tahap pertama terhadap anak berbeda dengan penahanan terhadap orang dewasa yaitu dilakukan hanya berlaku paling lama 7 (tujuh) hari dan apabila belum selesai, atas permintaan penyidik dapat diperpanjang oleh penuntut umum yang berwenang untuk paling lama 8 (delapan) hari.

Penahanan dilakukan dengan sungguhsungguh mempertimbangkan kepentingan anak dan/atau kepentingan masyarakat. Penyidik melakukan tindakan penahanan, harus terlebih dahulu mempertimbangkan dengan matang akibat dari tindakan penahanan, dari segi kepentingan anak seperti pertumbuhan dan perkembangan anak baik fisik, mental maupun sosial.

Tempat penahanan anak, harus dipisahkan dari tempat penahanan orang dewasa dan selama anak ditahan kebutuhan jasmani, rohani dan sosial anak harus tetap dipenuhi (Pasal 33 ayat (4) dan (5) UU No. 11 Tahun 2012). Dilatarbelakangi oleh pertimbangan psikologis, untuk menghindari akibat negatif sebab anak yang ditahan belum tentu terbukti melakukan tindak pidana dan bergaul dengan narapidana dikhawatirkan dapat menularkan pengalaman-pengalamannya kepada anak yang berstatus tahanan dan mempengaruhi perkembangan mentalnya, maka anak-anak yang ditahan ditempatkan lembaga penempatan anak sementara (LPAS) dan lembaga penyelenggaraan kesejahteraan sosial (LPKS) apabila LPAS belum tersedia.

Dalam Undang-Undang No. 11 Tahun 2012 mengutamakan pendekatan Keadilan Restoratif dan Diversi. Pasal 1 angka 6 mem- berikan pengertian Keadilan Restoratif adalah penyelesaian perkara tindak pidana melibatkan pelaku, korban, keluarga pelaku/korban dan pihak terkait untuk bersama-sama mencari menyelesaikan yang adil dengan menekankan pemulihan kembali pada keadaan semula dan bukan pembalasan, sedangkan diversi adalah pengalihan penyelesaian perkara anak dari proses peradilan pidana ke proses di luar pengadilan pidana (Pasal 1 angka 7 UU No. 11 tahun 2012).

Dalam Pasal 8 UU No.11 Tahun 2012 dirumuskan bahwa proses diversi dilakukan melalui musyawarah dengan melibatkan anak dan orng/wali, korban dan/orang/wali, pembimbing kemasyarakatan dan pekerja sosial profesional berdasarkan pendekatan Keadilan Restoratif. Dalam hal diperlukan mesyawarah dapat melibatkan tenaga kesejahteraan sosial dan/atau masyarakat. Proses Diversi wajib memperhatikan kepntingan korban, kesejahtraan dan tanggung jawab anak, penghindaran stigma negatif, penghindaran pembalasan dan keharmonisan masyarakat serta kepatutan, kesusilaan dan ketertiban umum.

Penyidik, Penuntut Umum dan Hakim dalam melakukan Diversi harus juga mempertimbangkan kategori tindak pidana, umur anak, hasil penelitian kemasyarakatan dari Bapas dan dukungan lingkungan keluarga dan masyarakat. Kesepakatan Diversi untuk menyelesaikan tindak pidana berupa pelanggaran, tindak pidana ringan, tindak pidana tanpa korban, nilai kerugian korban tidak lebih dari upah minimum provinsi setempat dapat dilakukan penyidik bersama pelaku atau keluarganya, pembimbing kemasyarakatan dan tokoh masyarakat. Kesepakatan Diversi yang dilakukan oleh penyidik atas rekomendasi Pembimbing Kemasyarakatan dapat berbentuk pengembalian kerugian dalam hal ada korban, rehabilitasi medis dan psikososial, penyerahan kembali pada orang tua/ wali, keikutsertaan dalam pendidikan dan pelatihan dalam lembaga pendidikan paling lama 3 bulan serta pelayanan masyarakat paling lama 3 bulan.

Hasil Diversi terhadap Anak yang berkonflik dengan hukum, dapat berbentuk perdamaian dengan tanpa ganti kerugian, 
penyerahan kembali pada orang tua/wali, keikutsertaan dalam pendidikan dan pelatihan dalam lembaga pendidikan paling lama 3 bulan serta pelayanan masyarakat paling lama 3 bulan.

Selain ketentuan Undang-Undang No.11 Tahun 2012 tentang Sistem Peradilan Pidana Anak. Elemen kelembagaan yang terlibat dalam penanganan anak yang berhadapan dengan hukum, juga membuat kesepakatan bersama dalam penanganan $\mathrm{ABH}$ yang termuat dalam Keputusan Bersama Ketua MA RI; Jaksa Agung RI; Kepala Kepolisian Negara Republik Indonesia; Menteri Hu- kum dan HAM RI; Menteri Sosial RI; Menteri Pemberdayaan Perempuan dan Perlindungan Anak RI; No.166A/KMA/SKB/XII/2009; No.148A/A/JA/12/2009; No.B/45/XII/2009; No.M.HH-08 HM.03.02 TAHUN 2009; No.10/PRS-2/KPTS/2009; No.02/Men.PP dan PA/XII/2009 TENTANG PENANGANAN ANAK YANG BERHADAPAN DENGAN HUKUM. Maksud dan tujuan dibuatnya keputusan bersama antara lain :
a. Mewujudkan koordinasi dan keterpaduan $\mathrm{APH}$ dan dan pihak yang terkait dalam penanganan $\mathrm{ABH}$
b. Persamaan Persepsi diantara jenjang

Skema 1 Pelaksanaan ABH di Tiap Unit Kerja

\begin{tabular}{|c|c|c|c|c|c|}
\hline & & & & & \\
\hline MA & JAKGUNG & POLRI & KEMHUK\&HA & KEMSOS & KEMPP \& PA \\
\hline $\begin{array}{l}\text { a. Personil } \\
\text { b. Fasilitas Pra/ } \\
\text { Sarana } \\
\text { c. Diskusi } \\
\text { Rutin \& } \\
\text { Latihan } \\
\text { d. Menerbitkn } \\
\text { Sema/ } \\
\text { Perma dan } \\
\text { menyusun } \\
\text { SOP } \\
\text { e. Membentuk } \\
\text { Pokja } \\
\text { f. Sosialisasi } \\
\text { Internal } \\
\text { g. Efektifitas } \\
\text { fungsi } \\
\text { bimbingan } \\
\text { dan } \\
\text { pengawasn } \\
\text { ketua PT }\end{array}$ & $\begin{array}{l}\text { a. Personil } \\
\text { b. Fasilitas } \\
\text { ruang } \\
\text { pemeriksaan } \\
\text { c. Melakukan } \\
\text { tuntutan } \\
\text { d. Diskusi Rutin } \\
\text { dan latihan } \\
\text { e. Menerbitkan } \\
\text { SE/ } \\
\text { perjakgung/ } \\
\text { SOP/ JUKLAK } \\
\text { / JUKNIS } \\
\text { f. Membentuk } \\
\text { Pokja } \\
\text { g. Efektifitas } \\
\text { fungsi } \\
\text { bimbingan } \\
\text { dan } \\
\text { pengawasan } \\
\text { kajati }\end{array}$ & $\begin{array}{l}\text { a. Personil } \\
\text { b. Meningkatkn } \\
\text { UPPA dan } \\
\text { RPK } \\
\text { c. Melakukan } \\
\text { penyidikan } \\
\text { ABH } \\
\text { d. Diskusi rutin } \\
\text { dan diklat } \\
\text { h. Menerbitkan } \\
\text { SE/ perkapol/ } \\
\text { SOP/ JUKLAK } \\
\text { / JUKNIS } \\
\text { i. Membentuk } \\
\text { Pokja } \\
\text { e. Sosialisai } \\
\text { Internal }\end{array}$ & $\begin{array}{l}\text { a. Personil } \\
\text { Bapas, Rutan } \\
\text { Lapas } \\
\text { b. Menetapkan } \\
\text { kebijakan, } \\
\text { program, } \\
\text { kegiatan } \\
\text { c. Meningkatkn } \\
\text { yan Litmas, } \\
\text { Bimwas, } \\
\text { dampingan } \\
\text { thd ABH } \\
\text { d. Fasilitas pra/ } \\
\text { sarana } \\
\text { e. Menerbitkan } \\
\text { SOP } \\
\text { f. Membentuk } \\
\text { Pokja } \\
\text { g. Sosialisasi } \\
\text { Internal } \\
\text { h. Tenaga } \\
\text { Psikolog, } \\
\text { guru dan } \\
\text { medis }\end{array}$ & $\begin{array}{l}\text { a. Personil } \\
\text { Pekerja Sosial } \\
\text { b. Fasilitas } \\
\text { PanSos, } \\
\text { Marsudi } \\
\text { Putra, RSPA, } \\
\text { Pusat Trauma } \\
\text { c. Menerbitkan } \\
\text { dan } \\
\text { menyusun } \\
\text { SOP Juklak/ } \\
\text { Juknis } \\
\text { d. Membentuk } \\
\text { Pokja } \\
\text { e. Sosialisasi } \\
\text { Internal } \\
\text { f. Mendorong } \\
\text { peran } \\
\text { keluarga, } \\
\text { masyarakat } \\
\text { dan orsos, } \\
\text { LSM peduli } \\
\text { terhadap } \\
\text { ABH }\end{array}$ & $\begin{array}{l}\text { a. Merumuskn } \\
\text { Kebijakan } \\
\text { ABH } \\
\text { b. Melakukan } \\
\text { Koordinasi } \\
\text { sinkron dengn } \\
\text { K/L di Pusat, } \\
\text { Prop/Kab/ } \\
\text { Kota } \\
\text { c. Mlaksankn } \\
\text { Diklat } \\
\text { d. Menerbitkn } \\
\text { Permen \& } \\
\text { menyusun } \\
\text { SOP/ Juklak/ } \\
\text { Juknis } \\
\text { e. Mmbentuk } \\
\text { Pokja } \\
\text { f. Sosialisasi } \\
\text { Internal, } \\
\text { advokasi \& } \\
\text { fasilitasi } \\
\text { g. Mendorong } \\
\text { PSM } \\
\text { h. Melakukn } \\
\text { pmantauan, } \\
\text { analisis, } \\
\text { evaluasi \& } \\
\text { pelaporan }\end{array}$ \\
\hline
\end{tabular}


Skema 2 Penanganan ABH berdasarkan SKB

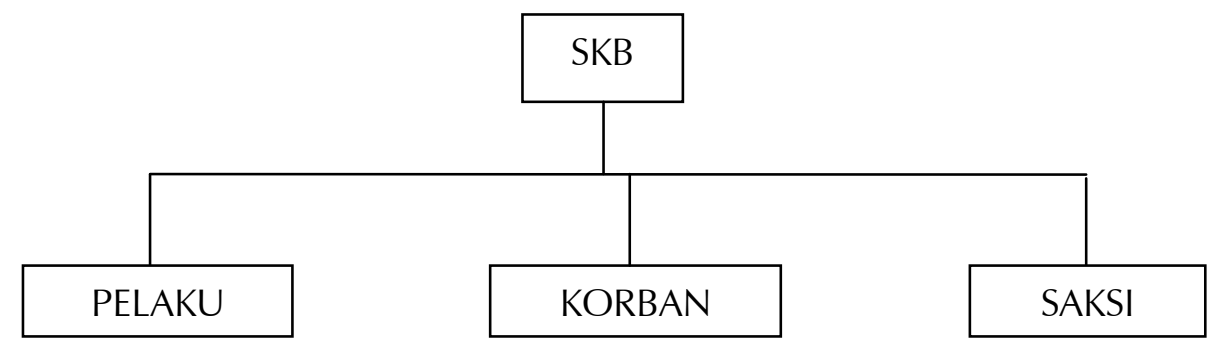

\begin{tabular}{|c|c|c|}
\hline $\begin{array}{l}\text { a. Penyidik libatkan Bapas } \\
\text { b. Bapas wajib buat litmas } \\
\text { c. Ditahan terpisah atau ti- } \\
\text { tip di RT Khusus Anak } \\
\text { d. JPU hasil Litmas dapat } \\
\text { RJ segera dilimpahkan } \\
\text { ke pengadilan } \\
\text { e. Hakim segera sidang } \\
\text { dengan pendekatan RJ } \\
\text { f. Putusan Hakim berupa } \\
\text { tindakan maka Bapas } \\
\text { wajib melakukan bim- } \\
\text { bingan dan pengawasan } \\
\text { g. Bimwas terpadu dengan } \\
\text { K/L terkait } \\
\text { h. Putusan hakim diserah- } \\
\text { kan ke dinsos }\end{array}$ & $\begin{array}{l}\text { a. Penyidikan lakukan in- } \\
\text { terview awal } \\
\text { b. Perhatikan kondisi dan } \\
\text { situasi awal korban } \\
\text { c. Apabila memerlukan } \\
\text { perawatan lebih lanjut } \\
\text { dirawat atau ditempat } \\
\text { di RPK untuk perawatan } \\
\text { medis, psikologi, sosial } \\
\text { d. Sembuh dan proses } \\
\text { hukum selesai, korban } \\
\text { dipulangkan atau dititip } \\
\text { ke RSPA, Rumah Aman, } \\
\text { Pusat Trauma untuk re- } \\
\text { hab mental dan sosial }\end{array}$ & $\begin{array}{l}\text { a. Penyidik hubungi ortu } \\
\text { / wali kecuali ortu/wali } \\
\text { terlibat } \\
\text { b. Membuat catatan iden- } \\
\text { titas, data, kronologi } \\
\text { dan kejadian } \\
\text { c. Meminta ortu/wali yang } \\
\text { dipercaya anak untuk } \\
\text { didampingi } \\
\text { d. Dilakukan di RPK tertu- } \\
\text { tup } \\
\text { e. Anak berhak mendapat- } \\
\text { kan perlindungan dari } \\
\text { LPSK } \\
\text { f. Rujukan jika perlu dira- } \\
\text { g. Perlu pendampingan }\end{array}$ \\
\hline
\end{tabular}

kerja dalam penanganan $\mathrm{ABH}$

c. Meningkatkan efektifitas penanganan $\mathrm{ABH}$ secara sistematis, komprehensif dan berkesinambungan;

d. Terjaminnya perlindungan khusus bagi anak melalui koordinasi dan kerjasama dalam penanganan $\mathrm{ABH}$.

Masing-masing lembaga yang telah bersepakat dalam SKB menjabarkan SKB dalam keorganisasaian lembaga secara internal yang terurai dalam skema 1.

\section{Simpulan}

Sistem Peradilan Pidana Anak wajib mengutamakan pendekatan Keadilan Restoratif (2) meliputi a. penyidikan dan penuntutan pidana anak dilaksanakan sesuai dengan ketentuan peraturan perundangan; b. persidangan anak yang dilakukan oleh pengadilan dilingkungan peradilan umum; dan c. pembinaan, pembimbingan, pengawasan, dan/ atau pendampingan selama proses pelaksanaan pidana atau tindakan dan setelah menjalani pidana atau tindakan.

Upaya Perlindungan terhadap Anak yang berhadapan dengan hukum dilakukan melalui Diversi berupa tindakan pengalihan penyelesaian perkara anak dari proses peradilan pidana ke proses diluar peradilan pidana. Diversi ini sangat membutuhkan penanganan khas anak yang bertujuan memberikan kepentingan terbaik bagi anak didukung oleh SDM Kepolisian yang memadai serta tersedianya bantuan hukum, pembimbingk masyarakatan, pekerja sosial professional serta dukungan keluarga/wali serta masyarakat.

\section{Daftar Pustaka}

Charles N. Swanson, Jr. Neil C. Chamelin, Leonard Terito, 1984, Criminal Investigation, Random House, New York, hlm. 4M. Nasir Jamil, 2013, Anak Bu- 
kan Untuk Dihukum, Jakarta: Sinar Grafika

Widodo, 2013, Prisonisasi anak Nakal:

Fenomena dan Penanggulangannya,

Yogyakarta: Aswaja Pressindo

Kitab Undang-undang Hukum Pidana

Kitab Undang-undang Hukum Acara Pidana

Undang-undang Nomor 11 Tahun 2012 tentang Sistem Peradilan Pidana Anak

Undang-undang Nomor 2 Tahun 2002 tentang Kepolisian Negara Republik Indonesia 